\title{
COVID-19 Pandemisinde Kullanılan İlaçlar, Etki Mekanizmaları ve Etkililikleri
}

\author{
Drugs Used in the Treatment of COVID-19 Pandemic, Their Mechanisms of Action and Efficacy
}

\section{Cansu Kılıç, Şule Aydın, Fatma Sultan Kılıç}

Eskisehir Osmangazi Üniversitesi

Tip Fakültesi Tibbi Farmakoloji Anabilim Dal, Eskişehir, Türkiye

Correspondence:

Fatma Sultan KILIC

Eskişehir Osmangazi Üniversitesi Tip Fakültesi Tibbi Farmakoloji Anabilim

Dalı, Eskişehir, Türkiye

e-mail: fskilic@ogu.edu.tr

\section{Özet}

Aralık 2019' da Çin' in Wuhan kentinde ortaya çıkan koronavirüs ailesinden olan COVID-19 tüm dünyada pandemiye yol açmıştır. Bu virüsün daha önce SARS-CoV ve MERS-CoV olarak salgın yapmış koronavirüsler ile genetik yakınlığı vardır. COVID-19 hastaları, ciddi akut respiratuvar sendrom (ARDS), ağır pnömoni tablosu, hematolojik bulgular, dissemine intravasküler koagülopati (DIC) ve sepsis gibi ağır tabloların yanısıra koku kaybı, bulantı, kusma, ishal gibi gastrointestinal sistem bulguları ya da sadece cilt döküntüleri ile de hastanelere başvurabilmektedirler. Akut dönemde makrofaj aktivasyon sendromu (MAS) ve sitokin fırtınası sebebiyle ağır inflamasyon tablosuna sebep olmaktadır. Tedavide, SARS-CoV ve MERS-CoV ile oluşan hastalık durumlarında kullanılan ilaçlar denenmektedir. Proflaksi ve tedavide klorokin, hidroksiklorokin kullanılırken ağır pnömoni durumlarında, ilave olarak azitromisin tedaviye eklenir. Hastalığın seyrine göre favipiravir, lopinavir, ritonavir, remdesivir, ribavirin gibi tedavide kullanılan/ denenen ilaçlara yardımcı ilaçlar olarak antisitokin-immunomodulatörler (tosilizumab, anakinra, sarilumab, bevasizumab, ekulizumab), kortikosteroidler, immünoglobilinler, interferonlar ve antiagregan-antiinflamatuvar (dipiridamol) ilaçlar kullanılır. Bu hastalığın seyri sırasında oluşabilecek koagülasyonu önlemek amacıyla profilaktik olarak düşük molekül ağırlıklı heparin (enoksaparin) kullanılabilir. COVID-19 semptomları mevsimsel ve semptomatik nedenlerle influenza ile karışabilir. İnfluenza olması durumunda tedavide oseltamivir kullanılır. Normal șartlarda herhangi bir tedavisi olmayan COVID-19 için aşı ve ilaç çalışmaları hız kazanmıştır. Ancak bu sürecin en az bir yıl kadar sürebileceğini söylemekte yarar vardır. Hatta bu hastalıkla mücadelede kök hücre çalışmaları da yapılmaktadır.

Anahtar kelimeler: Pandemi, koronavirüs, COVID-19, farmakolojik yaklaşımlar

\section{Abstract}

COVID-19, which belongs to a coronavirus family that emerged in Wuhan-China in December 2019, has caused pandemics worldwide. This virus has genetic affinity with previous coronaviruses, which have been outbreaks as SARS-CoV and MERS-CoV. COVID-19 patients have severe acute respiratory syndrome(ARDS), severe pneumonia, hematological findings, disseminated intravascular coagulopathy(DIC) and sepsis and also have signs of gastrointestinal system such as loss of smell, nausea-vomiting, diarrhea and sometimes only skin manifestations. In acute period, it causes severe inflammation due to macrophage activation syndrome(MAS) and cytokine storm. In treatment; drugs used in the treatments of SARS-CoV and MERS-CoV, are being tried. While chloroquine/ hydroxychloroquine are used in prophylaxis and treatment, in cases of severe pneumonia, azithromycin is additionally added to the treatment. According to the course of the disease, drugs which are used/being tried at the treatment such as favipiravir, lopinavir, ritonavir, remdesivir and ribavirin could be combined with adjuvant drugs such as anticytokine-immunomodulators (tocilizumab, anakinra, sarilumab, bevacizumab, eculizumab), corticosteroids, immunoglobulines, interferons and antiaggregant drugs (anti-inflammatory drugs) are used as auxiliary drugs. Heparin (enoxaparin) can be used prophylactically, to prevent coagulation in course of this disease. COVID-19 symptoms can be confused with influenza for seasonal and symptomatic reasons. In case of influenza, oseltamivir is used for treatment. Vaccine and drug studies have accelerated for COVID-19, which does not have any treatment under normal conditions. But it would be beneficial to mention that this process may take at least one year. In fact, stem cell studies are also carried out to combat this disease.

Keywords: Pandemic, coronavirus, COVID-19, pharmacological approaches 


\section{Giriș}

COVID-19 pandemisi aralık 2019' da Çin'in Wuhan kentinde başlayıp, koronavirüs (ciddi akut respiratuvar sendrom koronavirüsü) kaynaklı olarak ortaya çıkmıştır (1). Bu yeni beta koronavirüs (nCOV); SARS-CoV ve MERS-CoV ile genetik yakınlıklarına bağlı olarak oldukça benzerdir. $\mathrm{Bu}$ nedenle epidemiyolojik takip, tanısal testler, önleyici ve tedavi edici stratejilerin belirlenmesinde SARS-CoV' un viral genom dizilimi oldukça önemlidir (2).

Şu ana kadar COVID-19 vakalarında herhangi bir potansiyel tedavinin olduğuna dair bir kanıt olmamasına rağmen, bu yazıda olası tedavilerle ilgili bir derleme oluşturduk.

SARS ve MERS virüs tedavisinde etkili olan bazı ilaçların COVID-19 tedavisi için potansiyel aday olduğu düşünülmektedir. Aslında SARS ve MERS tedavisiyle ilgili çalışmaların meta analizleri de herhangi bir tedavi rejimine dair fark ortaya koyamamıştır $(3,4)$. COVID-19 tedavisi için bazı ümit vaad eden ilaçlarla olası tedaviler oluşturulmuştur. $\mathrm{Bu}$ olası tedaviler aşağıdaki şekillerde olabilmektedir.

\section{Klorokin ve Hidroksiklorokin}

Klorokin ve hidroksiklorokin, malaryanın önlenmesinde ve tedavisinde ve ayrıca sistemik lupus eritematozus ve romatoid artrit gibi inflamatuvar hastalıkların tedavisinde uzun süredir kullanılan ilaçlardır(5). Etkilerini konak hücrede glikolizasyonun, proteolitik sürecin ve endozomal asidifikasyonun inhibisyonu yoluyla virüsün hücreye girişini engelleyerek göstermektedirler. Ayrıca bu ajanlar konak hücrede sitokin üretiminde, otofaji ve lizozomal aktivitede azalma yoluyla immünmodülatör etki göstermektedirler $(6,7)$.

SARS ve MERS tedavisinde klorokin ve hidroksiklorokinin etkili olduğuna dair herhangi bir kanıt mevcut değildir. Ancak yapılan COVID-19 vakalarında radyolojik bulgularda iyileşme, viral arınmada artış ve hastalığın ilerlemesini sinırladığı bildirilmektedir (8). Fransa'da 36 hastayla yapılan bir çalışmada 8 saatte bir oral yoldan alınan $200 \mathrm{mg}$ dozunda hidroksiklorokinin standart destekleyici tedavi alan kontrol grubuna kıyasla virüs yükünü azalttığı bildirilmiştir. Çalışmayı yapanlar ayrıca 6 hastada hidroksiklorokin tedavisine azitromisin eklenmesinin hidroksiklorokin monoterapisine üstünlük gösterdiğini de bildirmiştir (9).

Hasta sayısının düşük olması ve hidroksiklorokin içeren ilaçların iyi tolere edilememesi ya da hastalı seyrinin kötüleşebilmesi gibi sebeplerden dolay1 tedavisinin erken sonlandırılması, ya da kombinasyonlarla kullanımında viral yük farkı ile farmakovijilans açısından klinik ve güvenlilik sonuçlarının belirtilememesi bu sinırlamalar arasında sayılabilir. $\mathrm{Bu}$ sinırlamalara kardiyotoksisite ile ilgili endişeler özellikle aritmiler de eklenmiştir.

Çin' de yapılan çalışmada günde $400 \mathrm{mg}, 5$ gün hidroksiklorokin tedavisi ve standart tedavi (destek tedavisi, interferon ve diğer antiviraller) alan veya sadece standart tedavi alan randomize 30 hastada virolojik bulgularda bir fark bulunamamıştır. 7. Günde bu iki grup arasındaki viral arınma $\% 86,7$ ' ye \%93,3 gibi bir oranla benzer bulunmuştur(10). Özellikle Sağlık çalışanlarında klorokin profilaksisi ve yüksek riskli temas sonrası profilaksisi ile ilgili çalışmalar da vardır. COVID-19 için klorokin tedavi dozu, günlük oral 1 veya 2 defa $500 \mathrm{mg}$ olduğu belirtilmekle beraber (11) klorokinin güvenlilik ve etkinliğinin hesaba katılması için hala veri yetersizliği mevcuttur.

SLE tedavisinde hidroksiklorokinin önerilen dozu günlük oral yoldan 400 mg' dır (12). Buna rağmen bir çalışmanın sonucuna göre ağır pnömonili COVID-19 için önerilen hidroksiklorokin optimal dozu ilk gün günde 2X400 mg yükleme dozu, sonrasında günde 2X200 mg şeklinde olmalıdır (13). Ancak her koşulda COVID-19 için en uygun dozun belirlenmesi için ileri çalışmalara ihtiyaç vardir.

SLE ve malarya hastalarından edinilen geniş çaplı tecrübelerden yola çıkılarak klorokin ve hidroksiklorokinin iyi tolere edilen ilaçlar olduğu söylenebilir. Yine de iki ajan nadiren 
olsa da hipotansiyon, kardiyomyopati, QT uzamas1, hipoglisemi, nöropsikiyatrik etkiler ve retinopati gibi ciddi yan etkilere sebep olabilir $(<\% 10)$. Ayrıca abdominal kramp, hepatotoksisite ve bu bağlamda karaciğer fonksiyon testlerinde artış, anoreksi, ishal, bulant1-kusma, ürtiker, anjiyoödem dahil anafilaktik reaksiyon gibi non-spesifik advers etkiler de görülmektedir. Makülopati ve maküler dejenerasyonlar geri döndürülemez olabilir. Uzun süreli veya yüksek dozda 4aminokinolin tedavisi alan hastalarda retinal pigmentasyon değişiklikleri (boğa gözü görünümü) ve görme alanı defektleri (parasantral skotomlar) ile geri dönüşümsüz retinopati bildirilmiştir. Nöronal sağırlık; kulak çınlaması, önceden var olan işitme hasarı olan hastalarda işitme azalması ve kaybı dışında; proksimal kas gruplarının progresif zayıflığ 1 ve atrofisine yol açan iskelet kası miyopatisi veya nöromiyopati, tendon reflekslerinin depresyonu ve anormal sinir iletimi de görülebilir. Ayrıca Pansitopeni, aplastik anemi, geri dönüşümlü agranülositoz, trombositopeni ve nötropeni ile G6PD (Glükoz 6 fosfat dehidrogenaz) eksikliği olan hastalarda hemolitik anemi de yapabilirler. Yan etkileri içinde nöropsikiyatrik değişimler; özellikle psikoz, deliryum, anksiyete, ajitasyon, uykusuzluk, konfüzyon, halüsinasyonlar, kişilik değişiklikleri, depresyon ve intihar davranışı gibi nöropsikiyatrik değişiklikler nadiren olsa da görülebilmektedir (14).

$\mathrm{Bu}$ nedenle bu ilaçların kullanımı sonucu mu, yoksa hastalı̆̆ın kendisi mi bu bulguları yapmaktadır, karışabilir. Klorokin yüksek dozlarda uygulanırsa veya kombinasyonlarla kullanımlarında bu türlü advers etkilerin oluşması riskinin daha fazla görülebileceği de oldukça açıktır.

COVID-19 tedavisi için ise belirlenen dozlar ve kullanım süresinin kısalığı nedeniyle klorokin için anlamlı bir yan etki bildirimi henüz olmamıştır. Gebelikte klorokin ve hidroksiklorokin kullanımı genel olarak güvenli kabul edilmektedir. 588 hastayı içeren 12 çalışma üzerine yapılan bir derlemede gebelikte kullanılan klorokin veya hidroksiklorokinin şimdiye kadar infantlarda oküler toksisiteye sebep olduğuna dair bir bulguya rastlanmamıştır (12). Olası İlaç-ilaç etkileşmelerini klorokin fosfat CYP2D6 ve CYP3A4 enzimleri aracilı yaparken; hidroksiklorokin fosfat CYP2D6 ve CYP3A4, CYP3A5 ile CYP2C8 enzimleri üzerinden etkilerini yapmaktadırlar $\mathrm{Bu}$ enzimlerle metabolize olan ilaçlarla özellikle etkileşme beklenmektedir(2).

Oxford Üniversitesinden Professor Peter Horby ve Prof Martin Landray in yürütücülüğünde yapılan bir klinik çalışmada tedavide hidroksiklorokinin etkisi araştırılmıştır. Bu çalışmada 1542 hasta bu ilaç ile tedavi olurken 3132 hastaya standart tedavi uygulanmıştır. 28 Günlük tedavi sonunda hidroksiklorokin kullananlarda \% 25,7 ölüm, kullanmayanlarda ise \% 23.5 ölüm görülmüştür. Sonuç olarak da hidroksiklorokin kullanımı ile ölümlerin arttığı bildirilmiştir (15).

Başka bir çalışmada ise COVID-19 la yüksek riskli veya orta derecede riskli maruziyetten sonra, hidroksiklorokin kullanıldığında veya 4 gün içinde maruz kalma sonrası profilaksi olarak kullanıldığında COVID-19 ile uyumlu hastalığ önlemediği de bildirilmiştir (16).

\section{Favipiravir}

T-705 olarak da bilinen bu ilacin ribofuranasil-5-trifosfat olan pürin nükleotidin ön ilacıdır. Virüs replikasyonunu durduran RNA polimeraz inhibitörüdür. Favipiravir ile ilgili preklinik çalışmaların çoğu aynı aileden olan Ebola ve influenza virüsleri içindir. Ancak diğer RNA virüslerine karşı da geniş aktiviteye sahiptir. COVID-19 tedavisi için bu ilacın yüksek dozları tercih edilmelidir (17). Tavsiye edilen yükleme dozu 12 saatte bir 2400-3000 mg'dır. İdame olarak ise 12 saatte bir 1200-1800 mg'dır. Yarılanma ömrü ise 5 saattir (18). Orta dozlarda iyi tolere edilirken yüksek dozlarda advers etkisi fazladır (17, 19). Özellikle hiperürisemi, ishal, nötrofillerde azalma ile transaminazlarda artmaya neden olurlar. İlaç-ilaç etkileşmelerini ise CYP2C8, aldehid oksidaz inhibisyonu ve ksantin oksidazlar aracilı oluşmaktadır (2). Şimdilerde Japonya' da influenza tedavisi için de kullanılmaktadır. 
COVID-19 tedavisinde kullanımları için hala sinırlamalar vardır. COVID-19 tedavisi için yapılan klinik çalışmalarda, favipiravir kullanan orta şiddetli olgularda daha iyi sonuç verirken, şiddetli olgularda istatistiksel olarak anlaml1l1k yoktur (20). Favipiravir ülkemizde COVID-19 tanısı alan bireylerde Klorokin ve hidroksiklorokin gibi rutin tedavide kullanılan bir ilaçdır. Ayrıca, önceki çalışmada favipiravir'in teratojenik bir ilaç olarak sınıflandırıldığını, yani gebeliğin erken devresinde embriyonun gelișmesini geciktirme ve ölümüne sebep olabilmektedir. Bunun dışında da 4 değişik tip hayvan türünde, maymunlar dahil, teratojenik etki gösterdiği belirlenmiştir. Hayvan deneylerinde yapilan histopatolojik tetkikler testislerde patolojik değişiklikler ve sperm hasarları tesbit edilmiştir. Çocuk doğurma çağında olan kadınlar ve bunların eşlerinin doğum kontrolü yöntemlerini kullanmaları gerekir. İlaç erkeklerde seminal sıvı ile uterusa erişebilir, spermde hasara sebep olabilir ve bu ilacı kullanan erkeklerin fertilize ettiği embriyolarda da terotojenik etki görülebilir. İlaç verilmeden önce kadınlarda mutlak gebelik testi yapılmalıdır, buna rağmen gebeliğin erken dönemimde testlerin negatif sonuç verebileceği de unutulmamalıdır (21).

Başka bir çalışmada da Umifenovir ile karşılaştırıldığında çok etkili bulunmamakla birlikte özellikle ateş ve öksürük şikâyetlerini azalttığı bildirilmiştir (22)

Diğer ciddi yan etkileri arasında şok, anaflaksi, pnömoni, fulminan hepatit, sarılık, toksik epidermal nekroliz, Stevens-Johnson sendromu, akut böbrek hasarı, löksit-nötrofil ve trombosit sayılarında azalma, şuur bozukluğu, anormal davranıșlar, deliryum, hallusinasyonlar, delüzyon, konvülziyonlar, hemorajik kolit sayılabilir (23).

\section{Lopinavir/ ritonavir ve Diğer Antiretroviraller}

Lopinavir/ritonavir FDA tarafindan HIV tedavisi için onay almış olup, 3-kemotripsin benzeri proteaz (3CL proteaz) inhibisyonu aracılığıyla koronavirüslere karşı in vitro aktivite göstermektedir (24, 25). Bu kombinasyonla ilgili SARS ve MERS tedavisi üzerine yapılan sınırlı sayıda çalışma mevcuttur ve bunların çoğu SARS üzerinedir. İlaç uygulamasının erken viral replikasyon pikinde yapılması oldukça önemlidir. Çünkü bu ajanlarla geç başlanan tedavinin klinik sonuçlar üzerinde hiçbir etkisinin olmadığı görülmüştür. Lopinavir/ritonavir' in COVID19 tedavisinde etkisi ile ilgili ilk yayınlanan sonuçlar genellikle küçük çaplı retrospektif randomize olmayan kohort çalışmalar ve olgu sunumlarının sonuçlarıdır. $\mathrm{Bu}$ da lopinavir/ritonavirin tedavisinin COVID-19 üzerine etkilerini belirlemeyi güç hale getirmiştir $(26,27)$.

Lopinavir/ritonavir kullanımı en fazla 14 gün boyunca günde iki defa $400 \mathrm{mg} / 100 \mathrm{mg}^{\text {‘d }} \mathrm{rr}$. Bu tedavi uygulanırken beraberinde kullanılan diğer ilaçların dikkatle seçilmesi ve monitorizasyonun sağlanması oldukça önemlidir. En s1k görülen gastrointestinal yan etkiler arasinda bulantı, kusma, ishal, pankreatit, hepatotoksisite ve kalpte iletim anormallikleri sayılabilir (28). COVID-19 hastalarında kombinasyon tedavisi bu yan etkileri daha da arttırabilir. Çünkü COVID-19 hastalarının yaklaşık \%20-30' u artmış transaminazlarla karşımıza çıkmaktadır (26). Son zamanlarda yapılan bir çalışmada bu tedavi rejimini alan hastaların yaklaşık \%50, sinde gastrointestinal yan etkiler görüldüğü ve $\% 14$ ' ünün bu yan etkiler sebebiyle tedaviye devam edemediği bildirilmiştir (28). Artmış alanin transaminaz seviyesi pek çok COVID19 araştırmasında red kriteri olarak kabul edilmiştir. Bu nedenle lopinavir/ ritonavir'e bağlı gelişen hepatotoksisite, hastaların diğer ilaçlardan faydalanmasını kısıtlamaktadır. Major ilaç-ilaç etkileşimlerinde de CYP 3A4 enzim inhibisyonu önemlidir. Ayrıca Pglikoproteinlerinde rolü vardır (2). $\mathrm{Bu}$ ilaçlarla ilgili 127 hastada yapılan bir çalışmada tek başlarına değil, İnterferon 1 beta ve ribavirin ile kombine kullanıldıklarında tedavide daha etkili bulunmuşlardır (29). Başka bir çalışmada da lopinavir-ritonavir in özellikle şiddetli COVID-19 lu hastalarda tedavi edici bir yararının olmadığı yönündedir (28). 


\section{Remdesivir}

Nükleotid analoğu olarak tanımlanan Remdesivir, antiviral ilaçlar grubundadır. Bir adenozin nükleotid analoğu olup etken maddesi GS-441524 adlı aktif bir maddedir. Hücre içinde nükleotid (adenosine nükleotid trifosfat) anoloğu olarak viral RNA bağıml RNA polimeraz etkisini azaltarak viral RNA oluşumunu azaltmaktadır. $\mathrm{Bu}$ ilaç koronavirüs, flavivirüs gibi RNA virüslere karşı antimikrobiyal tedavi taramaları sırasında keşfedilmiştir. Remdesivir, özellikle Ebola virüsün yoğun yaşandığ1 süreçte yapılan araştırma ve geliştirme çalışmaları sirasında konak polimeraz selektivitesi göstermiştir (30). Remdesivir geniş spektrumlu olup, birçok $\mathrm{CoV}$ virüsler enfeksiyonlara karş1 güçlü aktivite gösterir (31). Deneysel olarak yapılan MERS-CoV ile enfekte fare akciğerlerinde remdesivir, diğer tedavilerle karşılaştırıldığında, akciğer hemorajileri ve viral akciğer bulgularını azaltmıştır (32).

Klinik çalışmalarla Faz-1 aşamasında tek ve çoklu dozlarının kullanımı ile farmakokinetik ve güvenlik çalışmaları da yapılmıştır. 3-225 $\mathrm{mg}$ iv dozlarının karaciğer ve böbrek fonksiyonları açısından iyi tolere edildiği, yarılanma ömrünün 35 saatten fazla olduğu bildirilmiştir. Çoklu dozları izlendiğinde ise reversibl olarak aspartat aminotrasferaz, alanin transaminaz aktivitesi artmıştır. Bu süreçte ne hepatik ne de renal patoloji gösterilmemiş fakat tedavinin başlangıcında hastalarda glomerüler filtrasyon hizı $30 \mathrm{~mL} / \mathrm{min}$ olmuştur. İlk klinik kullanımları ebola virüs tedavisidir (33). Bununla birlikte COVID-19 için tedavide başarılı olabileceği bildirilmişsir (34). Orta ya da şiddetli COVID19 hastaları için antiviral etkinliği konusunda klinik çalışmalar devam etmektedir. Bu ilacın COVID-19 tedavisinde kullanımı için FDA Mayıs 2020 de "acil kullanım izni" ni 2 çalışmaya dayanarak vermiştir. Birinci araştırma Wang ve ark. tarafindan 237 hastada yapilan ve remdesiviri etkisiz bulan çalışmadır (35). Diğeri ise ABD Ulusal Sağlık Enstitüsü (NIH) tarafindan desteklenen ACTT-1 çalışmasıdır. Bu klinik araştırmada 10 günlük remdesivir kürü alan hastaların standart tedaviye göre hastanede yatma sürelerinin 4 gün kısaldığ1 (15 gün yerine 11 gün), fakat ölüm oranında bir değişiklik yapmadığı ortaya çıkmıştır (36). Özellikle advers etkileri açısından gebeler ve 18 yaş altı çocuklarda incelenmeye ihtiyacı vardır. Reversibl olarak transaminazları artırırlar. Ayrıca nefrotoksiktirler, özellikle kreatin klerensinde azalmaya neden olurlar. İlaç-ilaç etkileşmelerinde ise CYP3A4 enzim inhibisyonu ya da indüksiyonu yaptığına dair önemli bir bilgi de yoktur (2) Remdesivirin etkinliğine dair hala sorunlar ve şüpheler devam etmektedir. $\mathrm{Bu}$ nedenlerle ilacin kullanılabileceği optimal hasta topluluğu ve tedavi süresi de henüz bilinmemektedir. $\mathrm{ABD}$ ve Avrupa'da ruhsat almış olup, bu ilacın COVID-19 da kullanımı ile ilgili olarak birçok bilinmezinin olduğu da bir gerçektir.

\section{Ribavirin}

Ribavirin, viral RNA bağımlı RNA polimerazı inhibe eden bir guanin analoğudur. Diğer Corona ailesi üzerine olan etkisi onu COVID19 tedavisi için de bir aday haline getirmiştir. Bununla birlikte ribavirinin SARS-CoV üzerine in vitro etkinliği kısıtlıdır ve viral replikasyonun inhibisyonu için yüksek konsantrayonu ve ya kombine tedavi olarak uygulanması gerekmektedir. Yapilan çalışmalarda hastalara intravenöz ve enteral uygulama yapılmıştır. Ama inhale tedaviye dair bir kanit bulunmamaktadır $(3,37)$.

Ribavirin kullanımı sırasında oluşabilecek advers etkiler açısından en çok doz bağımlı şiddetli hematolojik toksisite görülmektedir. $\mathrm{Bu}$ bağlamda yapılan SARS çalışmalarında uygulanan yüksek doz ribavirin tedavisi sirasinda hastaların \%60' indan fazlasinda hemolitik anemiye sebep olduğu gözlenmiştir (3). Benzer endişeler MERS üzerine yapılan en büyük gözleme dayalı çalışmada da ribavirin ve interferon tedavisi alan hastalarin yaklaşık \%40'ında kan transfüzyonu gereksiniminin ortaya çıkmasıyla yaşanmıştır (38). SARS tedavisi için ribavirin kullanan hastaların \%75'inde ise transaminazlar yükselmiştir (3). Ribavirin teratojen olduğu için gebelikte de kontrendikedir (39).

Ribavirinin SARS, MERS gibi coronalar üzerine etkisine dair yetersiz veriler ve 
hepatotoksisitesi, nefrotoksisitesi ve gebelerde ki teratojenitesi göz önüne alındığında, COVID-19 tedavisinde sinırlı bir yeri olduğu söylenebilir. Eğer kullanılacaksa da, lopinavir-ritonavir ile kombinasyon şeklinde kullanımı en fazla klinik yararı sağlayacak kullanım şekli olacaktır (29). Bu pandemi sürecinde standart bir tedavi protokolü olarak da ne tek başına, ne de kombine olarak ülkemizde ve üniversitemizde kullanılamamıştır.

\section{Oseltamivir}

Oseltamivir, İnfluenza tedavisi için onay almış bir nörominidaz inhibitörü ilaç olup, SARS-CoV-2' ye karşı etkili olduğu konusunda herhangi bir bilgi yoktur. COVID19 ortaya çıktığında, influenzanın pik yaptığı mevsim olmasi nedeniyle tan1 konuncaya kadar olan süreçte hastaların tedavisinde kullanılmıştır (40). Bu ilaçla bağlantılı birçok klinik çalışmaların sonucunda da COVID-19 ile ilgili bir tedavi sağlamadığı görülmüştür. $\mathrm{Bu}$ nedenle; COVID-19 ile bulgular açısından özellikle bahar aylarında karışan influenza hastalığı tedavisinde spesifik olarak etki göstermektedir.

Arbidol olarak da bilinen diğer bir influenza tedavisinde kullanılan ilaç olan umifenovir ise zarflı, virüslerin membran geçişlerini inhibe eden ve S-protein/ACE2 enzimini hedef alarak etki göstermeyi amaçlayan bir ajandır (41). Bu ilaç Rusya ve Çin’ de influenza proflaksisi ve tedavisi ile SARS için kullanılabileceği yönündeki çalışmalardan yola ç1karak COVID-19' un tedavisinde kullanılmak üzere onay almıştır (42). Bu ilaç; influenza tedavisi için günde her 8 saatte 200 mg oral olacak şekilde kullanılmakta olup, COVID-19 tedavisinde kullanilacak dozu henüz belli değildir. Randomize yapılan bir çalışmada tedavide 9 gün kullanan hastalar bu tedaviyi hiç almayan hastalarla kıyaslandığında düşük mortalite hızı oluşturmuştur (\%0-16) (43). Aslında bu sınırlı hastada yapılan gözlemsel çalışma, umifenovirin COVID-19 tedavisi için etkili olduğunu da göstermez. İleri çalışmalara ihtiyacı olan bir çalışmadır. Bu ilaç kullanımı sırasında ciddi alerjik reaksiyonlar, hepatotoksisite, transaminazlarda belirgin artma ile gastrointestinal sistem bulguları görülmektedir. İlaç-ilaç etkileşmelerini de CYP3A4 enzim inhibisyonu/ indüksiyonu şeklinde oluşturmaktadır (2).

\section{İnterferonlar}

İnterferon alfa ve beta nın; koronavirüs tedavisinde, özellikle interferon beta nın ise MERS tedavisinde etkili olabileceğine dair çalışmalar mevcuttur $(3,4)$. Bunlar da diğer ilaçlar gibi gecikmiş tedavide etkinliğini sınırlayabilir. Ancak klinik çalışmalarla, in vitro ve diğer deneysel çalışmalar arasında fikir ayrılıkları olabilir. Yapılan çalışmalar, interferonların SARS-CoV-2 tedavilerinde kullanılmasını önermemektedir. Baricitinib, imatinib, dasatinib ve siklosporin gibi çeşitli immunomodülatör ilaçların, SARS-CoV-2 inhibisyonundaki olasi mekanizmalar üzerinde etkileri vardır (44-48). Bununla beraber bu ilaçları tedavide kullanmak için ne hayvan ne de insan çalışmaları yeterli değildir. $\mathrm{Bu}$ ajanların koruyucu oldukları düşünülebilir.

Akut respiratuvar distres sendromlarında (ARDS) ve akut akciğer enfeksiyonları ile oluşan inflamasyonu önlemede kullanılırlar. Bununla beraber sekonder enfeksiyon oluşumuna da zemin hazırlarlar. $\mathrm{Bu}$ grup ilaçların COVID-19 tedavisinde kullanımları ile ilgili olarak sınırlamalar olmakla beraber diğer viral pnömonilerin tedavisi için kullanılabilirler (49). Yapılan çalışmalarda kan ve solunum yollarından virüsün temizlenmesini geciktirdiği, sağ kalımda artmaya neden olmadikları, hiperglisemi, psikoz ve vasküler nekroz geliştirdikleri gösterilmiştir. Yapılan klinik bir çalışmada ise influenze pnömonisi tedavisi için kullanılmış olup mortalite ve sekonder enfeksiyon riskini artırmışlardır (50). Viral enfeksiyonlardan ziyade bakteriyal enfeksiyonlarda etkili oldukları düşünülmektedir (49). COVID-19' lu hastalarda ARDS gelişen olgularda metil prednizolon kullanımı ile ölüm riskinin azaldığı bildirilmiştir (51). Kronik obstriktif akciğer hastalığ $(\mathrm{KOAH})$ alevlenmelerinde veya inatçı şok durumlarında ki COVID-19' lu hastalar için önerilebilirken yine de rutin tedavide yararından ziyade potansiyel bir zararı söz konusu olabilir. Sonuç olarak 
Mekanik olarak havalandırılan ARDS hastaları için, sistemik kortikosteroidlerin kullanımına lehinde veya aleyhinde öneride bulunmak için yeterli kanıt yoktur (52).

\section{İmmunomodülatörler ve Antisitokinler}

Monoklonal antikorlar, COVID-19' lu hastalarda yardımeı potansiyel ilaçlardır. Sitokin firtınası, immün yanıtlara bağlı oluşan akciğer ve diğer organ hasarlarında fizyopatolojik bozulmaların altında yatan nedenleri düzeltmede kullanilırlar (53). Özellikle IL- 6' nin inflammasyondan sorumlu olduğu ve IL-6 sitokinlere karşı bu monoklonal antikorların kullanıldığ 1 çalışmalar vardır (54). Bunlara örnekler verecek olursak; tosilizumab (Actemra), IL-6 reseptör antagonisti monoklonal antikor olup, romatoid artrit tedavisi ve sitokin salıverilmesi sendromlarında kullanılması için FDA onaylıdır. Makrofaj Aktivasyonu Sendromunun (MAS) sitokin firtınas durumunda ve şiddetli pnömonili COVID-19' lu hastaların erken döneminde başarı göstermiştir. ARDS ve çok daha eskiden beri bilinen sepsis seyrinde antisitokin tedavilerinin yararlı olabileceğine dair kesin bir veri bulunmamakta ve bu ilaçlar rutin tedavide kullanılmamaktadır. ARDS'ye neden olabileceğine dair veriler de mevcuttur. Günde 400 mg' lik tek dozu ile hastaların \%91' inde özellikle solunum fonksiyonlarında hızlı savunma mekanizmaları oluşmasında, yatan hastaların hizlı taburcu olmasinda katk1 sağlamıştır (55). Tosilizumab tek başına kullanılabildiği gibi kombinasyonlarla da kullanılabilmektedir. Tosilizumab gebelik, nötropeni, aktif tüberküloz, aktif hepatit $\mathrm{B}$ veya $C$, alerji, hipersensitivite varlığında kullanılmamalı, karaciğer fonksiyonları ve trombosit sayısı izlenmeli, divertikülit öyküsü olan hastalar gastrointestinal perforasyon açısından yakından izlenmelidir (2). Anakinra ise IL-1 blokaj1 yaparken, ciddi seyirli COVID-19 hastalığındaki etkinliği kontrollü klinik çalışmalarla araştırılmaktadır. MAS bulguları gelişen hastalarda, temin edilebildiğinde anakinra (rekombinant IL-1 reseptör antagonisti, kineret $100 \mathrm{mg}$ hazır enjektör) tedavisi de güvenli bir seçenektir. Kisa yarı ömrü (4-6 saat) ve ihtiyaca göre doz $(2-10 \mathrm{mg} / \mathrm{kg}$ ) ve uygulama yolunu (deri altı ya da intravenöz) ayarlama avantajları daha güvenli bir tedavi olanağı sunabilir. CRP sentezini engellemediğinden, anakinra tedavisi alan hastalarda CRP düzeyleri, akut faz yanıtını takipte güvenli bir test olarak kullanılabilir (53). Sarilumab da romatoid artrit için onaylı diğer bir IL-6 reseptör antagonistidir. Şiddetli pnömonili COVID19'lu hastalar için çalışmalar devam etmektedir Bevasizumab (antivasküler endoteliyal büyüme faktörü), fingolimod (Multipl sklerozis için onaylı immunmodulatör) ve ekulizumab ile ilgili çalışmalar devam etmektedir. Ekulizumab, sitokin salınımı ve endotel hasarı ile ilişkili TTP benzeri trombotik mikroanjiyopatide $\mathrm{C} 5 \mathrm{a}$ inhibitörü olarak etki gösterir (2). JAK inhibitörleri de (ruksolitinib ve diğerleri), antisitokin tedavilerin yetersiz olduğu durumlarda kullanılabilir. Sonuç olarak, tosilizumab, anakinra, sarilumab gibi antisitokin tedaviler, MAS klinik ve laboratuvar bulguları gelişen COVID-19 hastalarında, kontrolsüz enflamasyonu baskılamak amacıyla dikkatli bir şekilde kullanılabilir.

\section{İmmunoglobulinler}

Hiperimmün immunoglobilinler ve iyileşen hasta plazmasının kullanılması diğer bir yardımcı tedavi olarak düşünülmektedir (56). Enfekte olup en az 28 gün önce iyileşen hastalardan antikorları alınarak tedavide kullanılabilir. SARS ve MERS tedavilerinde de kullanılmışlardır $(57,58)$. 2009' da yapılan H1N1' li 93 hastada yüksek ve düşük riskli hastalar karşılaştırıldığında mortalitede belirgin azaltma oluşturmuşlardır (59). Ancak COVID 19 çalışmaları yapıldıkça hastalığı geçirmiş bireylerinde $\mathrm{IgG}$ lerinin hızla negatifleştiği, hastalığı geçirmiş olmanın bireyleri uzun süreli olarak bağışıklamadığı yönündedir. Böylece iyileşen hasta plazması kullanımı da bir çözüm gibi görünmemektedir. $\mathrm{Bu}$ nedenlerle ancak vireminin pik yaptığı, primer immün yanıtın henüz oluşmadığı hastalığın ilk 7-10 günü içinde ve gün aşırı 3 dozda kullanılması ile etkili olduğu gözlenmektetir. Yapılan bir çalışmada da $0,3-0,5 \mathrm{~g} / \mathrm{kg}$ dozda 5 gün iv kullanılan hastalarda başarılı sonuçlar alınmıştır (60). 
Koagülopati Tedavisinde Kullanılan İlaçlar

COVID-19 hastalığı sırasında ayrıca tromboembolik olay gelișimi de sıça gözlenmektetir. Hatta DİC (Dissemine intravasküler koagulopati) gelişmesi sonucu sepsisle hastalar hayatını kaybetmektedir. Virüsün ACE 2' ye bağlanması ile doğrudan endotel hasarı oluşturması, sepsiste gözlenen vasküler mikrotrombotik olay ile hareketsiz kalma, hastanede yatma ilişkili olarak koagülopati oluşmaktadır. Koagülopati gelişen hastalarda ise ölümlerin arttığ görülmüştür. Tüm COVID-19 hastalarına heparin profilaksisi uygulanmalıdır. İnflamasyon bulguları geçene kadar heparin profilaksi devamı önerilir. Düşük molekül ağırlıklı heparin olan Enoksaparin subkutan olarak yüksek dozda kullanımı önerilir (61). Antiinflamatuar ve antiagregan olarak dipiridamol (DIP) ile alakalı olarak yapılan bir çalışmada DIP verilen hastalarda (150mg/gün) hiperkoagulopatiyi önlediği gösterilmiştir. DIP' $\mathrm{n}$ antiagregan ve antinflamatuar etkisinin yanı sira fosfodiesteraz enzimini etkileyerek ve viral replikasyonunu önleyerek antiviral etkisi yapılan bir in vitro çalışmada gösterilmiştir (62). Respiratuar yetmezlik gelişmesi durumunda kanama riski göz önünde bulundurularak doku plazminojen aktivatörü (tPA) ve defibrotid tedavilerinin kullanımı konusunda tedavi önerileri de yer almaktadır. Ciddi ve ölümcül olgularda progresif inflamatuvar faktör firtınası ve koagülasyon bozukluklarının görülmesi kardiyovasküler komplikasyonların önüne geçilmesi gerektiğini işaret etmektedir. $\mathrm{Bu}$ sebeple, aspirinin virüs replikasyonunu inhibe edici, antikoagülan, platelet agregasyonunu inhibe edici ve antiinflamatuvar etkilerinin olması sebebiyle akciğer hasarına karş1 etki göstereceği belirtilmektedir. Aspirinin erken dönemde kullanımının ciddi olguların insidansını, hastanede yatış süresini ve kardiyovasküler semptomları azaltması beklenmektedir (63).

\section{Azitromisin}

COVID-19 nedeniyle yatış endikasyonu olan özellikle ağır pnömoni durumlarında kullanılan makrolid grubu bir antibiyotiktir. Evde izlenecek hastalarda ise hidroksiklorokinle beraber kullanımlarında kardiyotoksisite yapmaları nedeni ile azitromisin tercih edilmemelidir. Özelikle ileri yaşl1, kardiyak morbiditesi yüksek olan, QT' yi uzatan ilaçları kullanan ve elektrolit bozuklukları olan hastalarda risk daha yüksektir. Bu nedenle COVID-19 nedeniyle hidroksiklorokin ve azitromisin kombinasyonu başlanacak veya almakta olan hastalarda QT uzaması dolayısıyla ventriküler taşikardi açısından uyanık olunması hatta kardiyoloji konsültasyonu yapılarak karar verilmesi gereklidir. Tedaviye başlanıldığında, EKG çekilerek yakından izlenmeli, kardiyotoksik istenmeyen etki görülenlerde öncelikle azitromisin kesilmeli daha sonra hidroksiklorokinin önce dozu azaltılmalı, sorun devam ederse tamamen kesilmesi düşünülmelidir (64).

İlaç ilaç etkileşmesi ve tedavideki etkililiği için New York'ta COVID-19 tanısı ile hastaneye yatırilan hastalar arasında yapılan bir çalışma da, hidroksiklorokin, azitromisin veya her ikisi ile tedavi yapılan hastaların sonuçları; her iki tedaviyle karşılaştırıldığında, hastane içi mortaliteleri açısından anlamlı bir ilişki gösterilememiştir. Bununla birlikte, bu bulguların yorumlanmas1 için vaka sayısının yeterli olmayabilir(65).

COVID-19 pandemisi ölüm nedenleri arasında hastalarda pnömoni gelişmesi oldukça sıktır. Ayrıca normal şartlarda da bireyler çeşitli hastalıkları nedeniyle ilaçlar kullanmaktadırlar. Burada COVID-19 un özellikle pnomoni geliştirmesini hızlandırması anlaminda Antipsikotikler ve antidepresanlar, opioid analjezikler, antikolinerjik ilaçlar, gabapentinoidler, proton pompası inhibitörleri ve inhale kortikosteroidlerin katkısı olup, bu ilaçları kullanan hastalarda pnömoni riskini 1,2 ila 2,7 kat artırabildikleri gözlenmiştir (66). Özellikle yaşlı hastalar bu ilaçlardan bir veya birkaçını kullanıyor olabilir. $\mathrm{Bu}$ nedenlerle ilaç-ilaç etkileşmeleri ve farmakovijilans açısından uyanık olmak gerekmektedir.

\section{Sonuç}

COVID-19 pandemisi ile ilgili olarak birçok ilaç gerek proflaksi, gerekse tedavi sırasın da 
kullanılarak yaşamı uzatma ve tedavi sürecini hızlandırmada denenmekle beraber henüz bilinen bir ilacı ve aşısı yoktur. Dünya Sağlık Örgütü ve ABD Ulusal Sağlı Enstitüsü tarafından yürütülen çalışmalar göstermektedir ki 100 den fazla ilacın denenmesine rağmen henüz COVID-19'u tedavi eden veya bundan koruyan bir ilaç keşfedilmemiştir. Kullanılan bazı ilaçlar bazı

\section{KAYNAKLAR}

1. Zhu N, Zhang D, Wang W, Li X, Yang B, Song J, et al. A Novel Coronavirus from Patients with Pneumonia in China, 2019. $N$ Engl $J$ Med. 2020;382:727-33.

2. Sanders JM, Monogue ML, Jodlowski TZ, Cutrell JB. Pharmacologic Treatments for Coronavirus Disease 2019 (COVID-19): A Review. Jama. 2020.

3. Stockman LJ, Bellamy R, Garner P. SARS: systematic review of treatment effects. PLoS Med. 2006;3:e343.

4. Morra ME, Van Thanh L, Kamel MG, Ghazy AA, Altibi AMA, Dat LM, et al. Clinical outcomes of current medical approaches for Middle East respiratory syndrome: A systematic review and meta-analysis. Rev Med Virol. 2018;28:e1977.

5. Savarino A, Boelaert JR, Cassone A, Majori G, Cauda R. Effects of chloroquine on viral infections: an old drug against today's diseases? Lancet Infect Dis. 2003;3:722-7.

6. Zhou D, Dai SM, Tong Q. COVID-19: a recommendation to examine the effect of hydroxychloroquine in preventing infection and progression. J Antimicrob Chemother. 2020.

7. Devaux CA, Rolain JM, Colson P, Raoult D. New insights on the antiviral effects of chloroquine against coronavirus: what to expect for COVID19? Int J Antimicrob Agents. 2020;55:105938.

8. Gao J, Tian Z, Yang X. Breakthrough: Chloroquine phosphate has shown apparent efficacy in treatment of COVID-19 associated pneumonia in clinical studies. Biosci Trends. 2020;14:72-3.

9. Gautret P, Lagier JC, Parola P, Hoang VT, Meddeb L, Mailhe M, et al. Hydroxychloroquine and azithromycin as a treatment of COVID-19: results of an open-label non-randomized clinical trial. Int J Antimicrob Agents. 2020:105949.

10. Jun C, Danping L, Li L, Ping L, Qingnian X, Lu $\mathrm{X}$, et al. A pilot study of hydroxychloroquine in treatment of patients with common coronavirus disease-19 (COVID-19). . J Zhejiang Univ (Med Sci). 2020;49.

11. Colson P, Rolain JM, Lagier JC, Brouqui P, Raoult D. Chloroquine and hydroxychloroquine as available weapons to fight COVID-19. Int $J$ Antimicrob Agents. 2020;55:105932.

12. Osadchy A, Ratnapalan T, Koren G. Ocular toxicity in children exposed in utero to bulgularda iyileşme sağlamış olsa da COVID ölümlerini önleyememektedir. Aşı çalışmaları sonucunda EMA ve FDI tarafindan onaylanan aş1lar olsa da kısa ve uzun vadeli etkileri konusu net değildir. Aşı çalışmaları ilk günden beri hala hem ulusal hem de uluslararası merkezlerde hızla devam etmektedir. antimalarial drugs: review of the literature. $J$ Rheumatol. 2011;38:2504-8.

13. Yao X, Ye F, Zhang M, Cui C, Huang B, Niu P, et al. In Vitro Antiviral Activity and Projection of Optimized Dosing Design of Hydroxychloroquine for the Treatment of Severe Acute Respiratory Syndrome Coronavirus 2 (SARS-CoV-2). Clin Infect Dis. 2020.

14. Kalil AC. Treating COVID-19-Off-Label Drug Use, Compassionate Use, and Randomized Clinical Trials During Pandemics. Jama. 2020.

15. Peter Horby MM, Louise Linsell, Jennifer L Bell, Natalie Staplin, Jonathan Emberson, et al. Effect of Hydroxychloroquine in Hospitalized Patients with COVID-19: Preliminary results from a multicentre, randomized, controlled trial. 2020.

16. Boulware DR, Pullen MF, Bangdiwala AS, Pastick KA, Lofgren SM, Okafor EC, et al. A Randomized Trial of Hydroxychloroquine as Postexposure Prophylaxis for Covid-19. $N$ Engl $J$ Med. 2020;383517-25.

17. Sissoko D, Laouenan C, Folkesson E, M'Lebing $\mathrm{AB}$, Beavogui $\mathrm{AH}$, Baize $\mathrm{S}$, et al. Experimental Treatment with Favipiravir for Ebola Virus Disease (the JIKI Trial): A Historically Controlled, Single-Arm Proof-of-Concept Trial in Guinea. PLoS Med. 2016;13:e1001967.

18. Shiraki K, Daikoku T. Favipiravir, an antiinfluenza drug against life-threatening RNA virus infections. Pharmacol Ther. 2020;209:107512.

19. Chinello P, Petrosillo N, Pittalis S, Biava G, Ippolito G, Nicastri E. QTc interval prolongation during favipiravir therapy in an Ebolavirusinfected patient. PLoS Negl Trop Dis. 2017;11:e0006034.

20. Gordon DE, Jang GM, Bouhaddou M, Xu J, Obernier K, White KM, et al. A SARS-CoV-2 protein interaction map reveals targets for drug repurposing. Nature. 2020.

21. Nagata T, Lefor AK, Hasegawa M, Ishii M. Favipiravir: a new medication for the Ebola virus disease pandemic. Disaster Med Public Health Prep. 2015;9:79-81.

22. Chang Chen YZ, Jianying Huang, Ping Yin, Zhenshun Cheng, Jianyuan $\mathrm{Wu}$, Song Chen, Yongxi Zhang, Bo Chen, Mengxin Lu, Yongwen Luo, Lingao Ju, Jingyi Zhang, Xinghuan Wang. Favipiravir versus Arbidol for COVID-19: A Randomized Clinical Trial www.medrxiv.org2020 
23. Pilkington V, Pepperrell T, Hill A. A review of the safety of favipiravir - a potential treatment in the COVID-19 pandemic? J Virus Erad. 2020;6:4551.

24. Chu CM, Cheng VC, Hung IF, Wong MM, Chan $\mathrm{KH}$, Chan KS, et al. Role of lopinavir/ritonavir in the treatment of SARS: initial virological and clinical findings. Thorax. 2004;59:252-6.

25. de Wilde AH, Jochmans D, Posthuma CC, Zevenhoven-Dobbe JC, van Nieuwkoop S, Bestebroer TM, et al. Screening of an FDAapproved compound library identifies four smallmolecule inhibitors of Middle East respiratory syndrome coronavirus replication in cell culture. Antimicrob Agents Chemother. 2014;58:4875-84.

26. Yao TT, Qian JD, Zhu WY, Wang Y, Wang GQ. A systematic review of lopinavir therapy for SARS coronavirus and MERS coronavirus-A possible reference for coronavirus disease-19 treatment option. J Med Virol. 2020;92:556-63.

27. Chan KS, Lai ST, Chu CM, Tsui E, Tam CY, Wong MM, et al. Treatment of severe acute respiratory syndrome with lopinavir/ritonavir: a multicentre retrospective matched cohort study. Hong Kong Med J. 2003;9:399-406.

28. Cao B, Wang Y, Wen D, Liu W, Wang J, Fan G, et al. A Trial of Lopinavir-Ritonavir in Adults Hospitalized with Severe Covid-19. N Engl J Med. 2020;382:1787-99.

29. Hung IF, Lung KC, Tso EY, Liu R, Chung TW, Chu MY, et al. Triple combination of interferon beta- $1 \mathrm{~b}$, lopinavir-ritonavir, and ribavirin in the treatment of patients admitted to hospital with COVID-19: an open-label, randomised, phase 2 trial. Lancet. 2020;395:1695-704.

30. Siegel D, Hui HC, Doerffler E, Clarke MO, Chun $\mathrm{K}$, Zhang L, et al. Discovery and Synthesis of a Phosphoramidate Prodrug of a Pyrrolo[2,1f][triazin-4-amino] Adenine C-Nucleoside (GS5734) for the Treatment of Ebola and Emerging Viruses. J Med Chem. 2017;60:1648-61.

31. Wang M, Cao R, Zhang L, Yang X, Liu J, Xu M, et al. Remdesivir and chloroquine effectively inhibit the recently emerged novel coronavirus (2019-nCoV) in vitro. Cell Res. 2020;30:269-71.

32. Sheahan TP, Sims AC, Leist SR, Schäfer A, Won $\mathrm{J}$, Brown AJ, et al. Comparative therapeutic efficacy of remdesivir and combination lopinavir, ritonavir, and interferon beta against MERS-CoV. Nat Commun. 2020;11:222.

33. Jacobs M, Rodger A, Bell DJ, Bhagani S, Cropley I, Filipe A, et al. Late Ebola virus relapse causing meningoencephalitis: a case report. Lancet. 2016;388:498-503.

34. Holshue ML, DeBolt C, Lindquist S, Lofy KH, Wiesman J, Bruce H, et al. First Case of 2019 Novel Coronavirus in the United States. $N$ Engl $J$ Med. 2020;382:929-36.

35. Wang Y, Zhang D, Du G, Du R, Zhao J, Jin Y, et al. Remdesivir in adults with severe COVID-19: a randomised, double-blind, placebo-controlled, multicentre trial. Lancet. 2020;395:1569-78.

36. McMahon JH, Udy A, Peleg AY. Remdesivir for the Treatment of Covid-19 - Preliminary Report. $N$ Engl J Med. 2020;383:992-3.

37. Foolad F, Aitken SL, Shigle TL, Prayag A, Ghantoji S, Ariza-Heredia E, et al. Oral Versus
Aerosolized Ribavirin for the Treatment of Respiratory Syncytial Virus Infections in Hematopoietic Cell Transplant Recipients. Clin Infect Dis. 2019;68:1641-9.

38. Arabi YM, Shalhoub S, Mandourah Y, AlHameed F, Al-Omari A, Al Qasim E, et al. Ribavirin and Interferon Therapy for Critically Ill Patients With Middle East Respiratory Syndrome: A Multicenter Observational Study. Clin Infect Dis. 2020;70:1837-44.

39. Altınbas S, Holmes JA, Altınbas A. Hepatitis C Virus Infection in Pregnancy: An Update. Gastroenterol Nurs. 2020;43:12-21.

40. Wang D, Hu B, Hu C, Zhu F, Liu X, Zhang J, et al. Clinical Characteristics of 138 Hospitalized Patients With 2019 Novel Coronavirus-Infected Pneumonia in Wuhan, China. Jama. 2020;323:1061-9.

41. Kadam RU, Wilson IA. Structural basis of influenza virus fusion inhibition by the antiviral drug Arbidol. Proc Natl Acad Sci U S A. 2017;114:206-14.

42. Khamitov RA, Loginova S, Shchukina VN, Borisevich SV, Maksimov VA, Shuster AM. [Antiviral activity of arbidol and its derivatives against the pathogen of severe acute respiratory syndrome in the cell cultures]. Vopr Virusol. 2008;53:9-13.

43. Wang Z, Yang B, Li Q, Wen L, Zhang R. Clinical Features of 69 Cases with Coronavirus Disease 2019 in Wuhan, China. Clin Infect Dis. 2020.

44. Li G, De Clercq E. Therapeutic options for the 2019 novel coronavirus (2019-nCoV). Nat Rev Drug Discov. 2020;19:149-50.

45. Coleman CM, Sisk JM, Mingo RM, Nelson EA, White JM, Frieman MB. Abelson Kinase Inhibitors Are Potent Inhibitors of Severe Acute Respiratory Syndrome Coronavirus and Middle East Respiratory Syndrome Coronavirus Fusion. $J$ Virol. 2016;90:8924-33.

46. Dyall J, Gross R, Kindrachuk J, Johnson RF, Olinger GG, Jr., Hensley LE, et al. Middle East Respiratory Syndrome and Severe Acute Respiratory Syndrome: Current Therapeutic Options and Potential Targets for Novel Therapies. Drugs. 2017;77:1935-66.

47. Pfefferle S, Schöpf J, Kögl M, Friedel CC, Müller MA, Carbajo-Lozoya J, et al. The SARScoronavirus-host interactome: identification of cyclophilins as target for pan-coronavirus inhibitors. PLoS Pathog. 2011;7:e1002331.

48. de Wilde AH, Zevenhoven-Dobbe JC, van der Meer Y, Thiel V, Narayanan K, Makino S, et al. Cyclosporin A inhibits the replication of diverse coronaviruses. J Gen Virol. 2011;92:2542-8.

49. Russell CD, Millar JE, Baillie JK. Clinical evidence does not support corticosteroid treatment for 2019-nCoV lung injury. Lancet. 2020;395:473-5.

50. Ni YN, Chen G, Sun J, Liang BM, Liang ZA. The effect of corticosteroids on mortality of patients with influenza pneumonia: a systematic review and meta-analysis. Crit Care. 2019;23:99.

51. Wu C, Chen X, Cai Y, Xia J, Zhou X, Xu S, et al. Risk Factors Associated With Acute Respiratory Distress Syndrome and Death in Patients With 
Coronavirus Disease 2019 Pneumonia in Wuhan, China. JAMA Intern Med. 2020.

52. Coronavirus Disease 2019 (COVID-19) TreatmentGuidelines https://www.covid19treatmentguidelines.nih.gov [

53. Mehta P, McAuley DF, Brown M, Sanchez E, Tattersall RS, Manson JJ. COVID-19: consider cytokine storm syndromes and immunosuppression. Lancet. 2020;395:1033-4.

54. Zhou F, Yu T, Du R, Fan G, Liu Y, Liu Z, et al. Clinical course and risk factors for mortality of adult inpatients with COVID-19 in Wuhan, China: a retrospective cohort study. Lancet. 2020;395:1054-62.

55. Xu X, Han M, Li T, Sun W, Wang D, Fu B, et al. Effective treatment of severe COVID-19 patients with tocilizumab. Proc Natl Acad Sci U S A. 2020;117(20):10970-5.

56. Chen L, Xiong J, Bao L, Shi Y. Convalescent plasma as a potential therapy for COVID-19. Lancet Infect Dis. 2020;20:398-400.

57. Soo YO, Cheng Y, Wong R, Hui DS, Lee CK, Tsang KK, et al. Retrospective comparison of convalescent plasma with continuing high-dose methylprednisolone treatment in SARS patients. Clin Microbiol Infect. 2004;10:676-8.

58. Arabi Y, Balkhy H, Hajeer AH, Bouchama A, Hayden FG, Al-Omari A, et al. Feasibility, safety, clinical, and laboratory effects of convalescent plasma therapy for patients with Middle East respiratory syndrome coronavirus infection: a study protocol. Springerplus. 2015;4:709.

59. Hung IF, To KK, Lee CK, Lee KL, Chan K, Yan WW, et al. Convalescent plasma treatment reduced mortality in patients with severe pandemic influenza A (H1N1) 2009 virus infection. Clin Infect Dis. 2011;52:447-56.

60. Cao W, Liu X, Bai T, Fan H, Hong K, Song H, et al. High-Dose Intravenous Immunoglobulin as a Therapeutic Option for Deteriorating Patients With Coronavirus Disease 2019. Open Forum Infect Dis. 2020;7:ofaa102.

61. Tang N, Bai H, Chen X, Gong J, Li D, Sun Z. Anticoagulant treatment is associated with decreased mortality in severe coronavirus disease 2019 patients with coagulopathy. J Thromb Haemost. 2020;18:1094-9.

62. Liu X, Li Z, Liu S, Chen Z, Zhao Z, Huang Y-y, et al. Therapeutic effects of dipyridamole on COVID-19 patients with coagulation dysfunction. medRxiv; 2020.

63. Aliae A R Mohamed- Hussein KMEA, MohamedEltaher A A Ibrahim. Should aspirin be used for prophylaxis of COVID-19-induced coagulopathy? Medical Hypotheses. 2020;144.

64. Gurwitz D. Angiotensin receptor blockers as tentative SARS-CoV-2 therapeutics. Drug Dev Res. 2020.

65. Rosenberg ES, Dufort EM, Udo T, Wilberschied LA, Kumar J, Tesoriero J, et al. Association of Treatment With Hydroxychloroquine or Azithromycin With In-Hospital Mortality in Patients With COVID-19 in New York State. Jama. 2020;323:2493-502.

66. Joan-Ramon Laporte DH. In the midst of the SARS-CoV-2 pandemia, caution is needed withcommonly used drugs that increase the risk of pneumonia https://www.isdbweb.org2020 [ 